\title{
Preparation and Characterization of Bioplastics from Grass Pea Flour Cast in the Presence of Microbial Transglutaminase
}

\author{
C. Valeria L. Giosafatto ${ }^{1}{ }^{\mathbb{D}}$, Asmaa Al-Asmar ${ }^{1,2} \mathbb{1}$, Antonio D $^{\prime}$ Angelo ${ }^{1}$, Valentina Roviello ${ }^{3}$, \\ Marilena Esposito ${ }^{1}$ and Loredana Mariniello ${ }^{1, * \mathbb{D}}$ \\ 1 Department of Chemical Sciences, University of Naples "Federico II", \\ Complesso Universitario di Monte Sant'Angelo, Via Cinthia 4, 80126 Naples, Italy; \\ giosafat@unina.it (C.V.L.G.); asmaa.alasmar@unina.it (A.A.-A.); \\ antoniodangelo2601@gmail.com (A.D.); marilena.esposito2@unina.it (M.E.) \\ 2 Analysis, Poison control and Calibration Center (APCC), An-Najah National University, P.O. Box 7, \\ Nablus, Palestine \\ 3 CeSMA, University of Naples “Federico II", 80126 Naples, Italy; valentina.roviello@unina.it \\ * Correspondence: loredana.mariniello@unina.it; Tel.: +39-081-2539470
}

Received: 22 October 2018; Accepted: 23 November 2018; Published: 28 November 2018

\begin{abstract}
The aim of this work was to prepare bioplastics, from renewable and biodegradable molecules, to be used as edible films. In particular, grass pea (Lathyrus sativus L.) flour was used as biopolymer source, the proteins of which were structurally modified by means of microbial transglutaminase, an enzyme able to catalyze isopeptide bonds between glutamines and lysines. We analyzed, by means of Zeta-potential, the flour suspension with the aim to determine which $\mathrm{pH}$ is more stable for the production of film-forming solutions. The bioplastics were produced by casting and they were characterized according to several technological properties. Optical analysis demonstrated that films cast in the presence of the microbial enzyme are more transparent compared to the untreated ones. Moreover, the visualization by scanning electron microscopy demonstrated that the enzyme-modified films possessed a more compact and homogeneous structure. Furthermore, the presence of microbial transglutaminase allowed to obtain film more mechanically resistant. Finally, digestion experiments under physiological conditions performed in order to obtain information useful for applying these novel biomaterials as carriers in the industrial field, indicated that the enzyme-treated coatings might allow the delivery of bioactive molecules in the gastro-intestinal tract.
\end{abstract}

Keywords: grass pea; bioplastics; mechanical properties; transglutaminase; Zeta-potential

\section{Introduction}

Nowadays life without plastics seems to be unimaginable because of their important role in our society and applications in almost all the areas of daily life, from packaging to food, medical and communication technology to cars. The majority of these plastics are based on very unsustainable fossil resources, causing pollution that affects the entire environment. According to Geyer et al. [1], 8300 million metric tons ( $\mathrm{Mt}$ ) as of virgin plastics have been produced to date and in 2015, approximately $6300 \mathrm{Mt}$ of plastic waste had been generated, around $9 \%$ of which had been recycled, $12 \%$ was incinerated, and $79 \%$ was accumulated in landfills or in the natural environment. In order to reduce pollution from plastics, during the last few decades, researchers have been developing different technologies to produce new kind of biobased plastics and bioplastics that are similar or better than the traditional ones [2-4]. According to European Bioplastic [5], bioplastics are a large family of different materials that are either biobased and/or biodegradable. Among bioplastics, it is worthwhile to talk 
about edible films, that are important in the sector of food packaging and represent a potential new highly competitive market [6]. Edible films have received increasing attention mostly because of their advantages as components of food packaging over fossil-fuel materials [3,4]. An edible film is a preformed, thin layer, made of edible material, which can be placed either on or between food components, playing an important role on the conservation, distribution and marketing of foodstuff [7]. Some of its functions consist in protecting food products from mechanical damage, physical, chemical and microbiological activities $[6,8,9]$. The aim of this work was to prepare and characterize a new kind of hydrocolloid bioplastics, to be used as edible films, based on grass pea (Lathyrus sativus L.) flour, a legume from the family of Fabaceae $[10,11]$. Grass pea flour is very profitable because the legume is resistant to both abiotic (dryness, water stagnation and very poor and dry soils) and biotic (high capability to fix atmospheric nitrogen, high seeds and proteins yield) stresses [10]. The films were prepared by using grass pea flour either treated or not treated with microbial transglutaminase (mTGase, E.C. 2.3.2.13), an enzyme easily purified from the culture medium of Streptoverticillium mobaraense [12], able to catalyze the crosslinking of proteins via acyl transfer reactions between the $\gamma$-carboxamide group of glutamine residues and the $\varepsilon$-amino group of lysine residues, leading to the formation of inter-molecular and intra-molecular isopeptide bonds $[13,14]$. mTGase is $\mathrm{Ca}^{2+}$ independent, and it is active over a broad range of temperatures and $\mathrm{pHs}$ with an optimal activity at approximately $40^{\circ} \mathrm{C}$ and $\mathrm{pH}$ of 7-7.5. These properties are important prerequisites for an application of an enzyme in the industrial sector. The film forming solutions prepared by using grass pea flour modified or not by mTGase have been characterized and the resulting bioplastics investigated according to their transparency, microstructure and mechanical properties. Moreover, digestibility studies carried out under physiological conditions were performed in order to apply such bioplastics in either food or pharmaceutical sector.

\section{Materials and Methods}

\subsection{Materials}

Grass pea seeds were bought in a local supermarket (Naples, Italy). Microbial transglutaminase (ACTIVA WM, Ajinomoto, Tokyo, Japan, specific activity $92 \mathrm{U} / \mathrm{g}$ ) was purchased from Prodotti Gianni S.p.A. Milan, Italy. Glycerol, used as a plasticizer for the preparation of films, was purchased from Sigma (St. Louis, MO, USA). Acrylamide and Blue Brilliant Coomassie were purchased from Bio-Rad (Segrate, Milan, Italy). All other chemical reagents were purchased from the following companies: Amersham Pharmacia (Stockholm, Sweden), Merck (Rome, Italy), Roche (Grenzach-Wyhlen, Germany). The remaining chemicals and solvents used in this study were of analytical grade unless specified.

\subsection{Grass Pea Flour Characterization}

\subsubsection{Protein Content}

The amount of proteins was determined by measuring the nitrogen content of the material and multiplying that value by the factor 6.25 [15].

\subsubsection{Zeta-Potential and Particle Size of Grass Pea Flour Suspension}

The suspension was prepared dissolving the flour in distilled water at concentration of $1 \mathrm{mg} \mathrm{mL}^{-1}$. In order to sediment the starch, the sample was kept overnight at $4{ }^{\circ} \mathrm{C}$. After that, the sample was centrifuged at $10,000 \mathrm{rpm}$ for $5 \mathrm{~min}$ at the temperature of $10^{\circ} \mathrm{C}$ and the pellet was removed. Before the analysis, the supernatant was further filtrated with 0.45 micron filter and the $\mathrm{pH}$ was adjusted to 2 by using $\mathrm{HCl} 0.1 \mathrm{~N}$. A titration as function of $\mathrm{pH}$ (from 2 to 12) was carried out to measure Zeta-potential and particle size of grass pea flour suspension by means of Zetasizer Nano-ZSP (Malvern ${ }^{\circledR}$, Worcestershire, UK). As titrants we have used $0.01,0.1$ and $1 \mathrm{~N} \mathrm{NaOH}$ solutions, respectively. All results were analyzed by using the Zetasizer software (version 7.12). 


\subsection{Film Forming Solutions Preparation and Characterization}

\subsection{1. mTGase Preparation}

The enzyme solution was prepared by dissolving the commercial preparation "Activa" (containing $1 \%$ of enzyme and $99 \%$ of maltodextrins, specific activity $92 \mathrm{U} / \mathrm{g}$ ) in distilled water at a concentration of $20 \mathrm{U} \mathrm{mL}^{-1}$. The mixture was stirred for $10 \mathrm{~min}$ to allow the solubilization of mTGase preparation.

\subsubsection{Film Forming Solution (FFS) Preparation}

Flour (41.5 g) was dissolved in $500 \mathrm{~mL}$ of distilled water (concentration of $83 \mathrm{mg} \mathrm{mL}^{-1}$ ) and the stock solution was stirred for $1 \mathrm{~h}$. Afterwards the $\mathrm{pH}$ was adjusted from 6.5 to 9 with $\mathrm{NaOH}$ $1 \mathrm{~N}$. Then the solution was centrifuged at $10,000 \mathrm{rpm}$ for $10 \mathrm{~min}$ at $4{ }^{\circ} \mathrm{C}$ and the pellet was removed. The $\mathrm{pH}$ of supernatant was adjusted to 7 by adding $\mathrm{HCl} 1 \mathrm{~N}$ and the solution was centrifuged under the same conditions (described above) in order to remove additional aggregates. FFSs without mTGase were prepared by mixing $30 \mathrm{~mL}$ withdrawn from solution and mixed with $200 \mu \mathrm{L}$ (corresponding to $8 \%$ of glycerol in respect to protein content) of glycerol (100 $\left.\mathrm{mg} \mathrm{mL}^{-1} w / v\right)$ and $19.8 \mathrm{~mL}$ of distilled water. FFSs with mTGase were prepared as previously described and by adding $1 \mathrm{~mL}$ of mTGase (this amount corresponds to $33 \mathrm{U}$ of enzyme/g of protein). Both FFSs, treated or not with mTGase, were incubated for $2 \mathrm{~h}$ at $37^{\circ} \mathrm{C}$. After incubation, the $\mathrm{pH}$ of FFSs was adjusted to 9. The final volume of each solution was $50 \mathrm{~mL}$.

\subsubsection{Zeta-Potential and Particle Average Size}

Zeta-potential, average particle size, and polydispersity index of the FFSs, containing or not mTGase, were analyzed using the Zetasizer Nano-ZSP. Three independent Zeta-potential measurements at $\mathrm{pH} 9$ were carried out on each sample of FFSs $(1 \mathrm{~mL})$ introduced in the measurement vessel. Temperature was set up at $25{ }^{\circ} \mathrm{C}$, applied voltage was $200 \mathrm{mV}$ and duration of each analysis was approximately of $10 \mathrm{~min}$. The software calculated mean diameter of particles, determined at $\mathrm{pH} 9$ by using dynamic light scattering, and the polydispersity index, representing the relative variance in the particle size distribution. The device uses a helium-neon laser of $4 \mathrm{~mW}$ output power operating at the fixed wavelength of $633 \mathrm{~nm}$ (wavelength of laser red emission). All the results were reported as mean \pm standard deviation.

\subsubsection{Viscosity}

Standard Ostwald capillary viscometer was used for the experiments. The viscometer was thermostated to $30.0 \pm 0.1^{\circ} \mathrm{C}$ in a water bath. The flow time for water was approximately $83.3 \pm$ $0.1 \mathrm{~s}$. Flow times for the FFSs (untreated and treated with mTGase) were measured in duplicate using a stopwatch. Each FFS was diluted 1:2 starting from concentration of flour of $29.3 \mathrm{mg} \mathrm{mL}^{-1}$ to $1.83 \mathrm{mg} \mathrm{mL}^{-1}$. Specific viscosity was obtained by using the following equation:

$$
\text { Specific Viscosity }=(\text { FFS flow time }- \text { water flow time }) /(\text { water flow time })
$$

\subsection{Film Preparation and Characterization}

\subsubsection{Film Casting}

FFSs, prepared as described above, were poured in Petri's dishes and placed in a climatic chamber at $25^{\circ} \mathrm{C}$ and $45 \%$ of R.H. for $48-72 \mathrm{~h}$.

\subsubsection{Thickness}

Thickness was obtained using a micrometer (Metrocontrol Srl, Casoria, Naples, Italy, mod. H062 with the precision of $\pm 2 \mu \mathrm{m})$. The results were obtained measuring thickness in four random points, then the average and the standard deviation were calculated. 


\subsubsection{Opacity}

The opacity of each samples was investigated reproducing the method used by Shevkani et al. [16]. This method is based on the measurement of absorbance at $600 \mathrm{~nm}$ (spectrophotomer UV/Vis SmartSpec 3000 Bio-Rad, Segrate, Milan, Italy) divided by the thickness (mm). All the samples (our bioplastics and commercial material used for references) were cut into pieces of $1 \mathrm{~cm} \times 3 \mathrm{~cm}$ and they were let adhere perfectly to the wall of the cuvette.

\subsubsection{Scanning Electron Microscopy (SEM)}

SEM analysis of both surface and cross-section of grass pea flour-based films was carried out by using field emission scanning electron microscope (Nova NanoSem 450-FEI-Thermo Fisher, Scientific, Waltham, MA, USA). Briefly, the samples were placed on an aluminum stub by using a graphite adhesive tape. A thin coat of gold and palladium was sputtered at a current of $20 \mathrm{~mA}$ for $90 \mathrm{~s}$. The sputter-coated samples were then introduced into the specimen chamber and the images were acquired at an accelerating voltage of $3 \mathrm{kV},(4.4-5.2) \mathrm{mm}$ working distance, through the Everhart Thornley Detector (ETD, 450-FEI-Thermo Fisher, Scientific, Waltham, MA, USA). Two different samples of each type of films were subjected to SEM and four micrographs of each sample were taken. Micrographs of surfaces and cross-sections were obtained taking parts at $2600 \times$ magnification of the samples.

\subsubsection{Mechanical Properties}

Film tensile strength, elongation at break and Young's modulus were determined by using an Instron Universal Testing Instrument (model no. 5543A, Instron Engineering Corp., Norwood, MA, USA). Film sample strips ( $1 \mathrm{~cm}$ wide and $5 \mathrm{~cm}$ long), obtained by using a sharp razor blade, were equilibrated for $2 \mathrm{~h}$ at $50 \% \mathrm{RH}$ and $25^{\circ} \mathrm{C}$ in an environmental chamber, and four samples of each film type were tested. Tensile properties were measured according to the ASTM D882-97 [17]. The initial grip separation was $40 \mathrm{~mm}$, and the crosshead speed was $5 \mathrm{~mm} \mathrm{~min}^{-1}$ in tension mode. The acquisition and elaboration of the data were made by the using the software BlueHill 2.21.

\subsubsection{In Vitro Film Digestion}

The films prepared in the absence and in the presence of mTGase were subjected to a three-stage in vitro digestion by using adult model [18-20], under simulated oral, gastric and duodenal physiological conditions. For our analyses, $5 \mathrm{mg}$ of each type of films were incubated in $600 \mu \mathrm{L}$ of Simulated Salivary Fluid (SSF, $150 \mathrm{mM}$ of NaCl, $3 \mathrm{mM}$ of urea, pH 6.9) for $5 \mathrm{~min}$ at $170 \mathrm{rpm}$. Afterwards the samples were subjected to gastric and duodenal digestion as described by Giosafatto et al. [18] with some modifications. Briefly, aliquots $(100 \mu \mathrm{L})$ of Simulated Gastric Fluid (SGF, $0.15 \mathrm{M}$ of NaCl, $\mathrm{pH} 2.5$ ) were placed in $1.5 \mathrm{~mL}$ microcentrifuge tubes and incubated at $37^{\circ} \mathrm{C}$. $75 \mu \mathrm{L}$ of films dissolved in SSF, the $\mathrm{pH}$ of which was adjusted to 2.5 with $\mathrm{HCl} 6 \mathrm{M}$, were added together with pepsin (1:20 $w / w$ respect to grass pea protein content) to each of the SGF vials to start the digestion reaction. At intervals of 1, 2, 5, 10, 20, 40, $60 \mathrm{~min}, 40 \mu \mathrm{L}$ of $0.5 \mathrm{M}$ of ammonium bicarbonate $\left(\mathrm{NH}_{4} \mathrm{HCO}_{3}\right)$ were added to each vial to stop the pepsin reaction. The control was set up by incubating the sample for $60 \mathrm{~min}$ without the protease. Duodenal digestions were performed using, as the starting material, the gastric digests after $60 \mathrm{~min}$, adjusted to $\mathrm{pH} 6.5$ with $0.5 \mathrm{M}$ Bis-Tris $\mathrm{HCl} \mathrm{pH}$ 6.5. Bile salts (sodium taurocholate and sodium glycodeoxycholate) dissolved in Simulated Duodenal Fluid (SDF, $0.15 \mathrm{M}$ of $\mathrm{NaCl}$ at $\mathrm{pH}$ 6.5) were added to a final concentration of $4 \mathrm{mM}$. After equilibrating at $37^{\circ} \mathrm{C}$ for $10 \mathrm{~min}$, trypsin, chymotrypsin (the ratio of trypsin and chymotrypsin with test proteins was 1:400 $(w / w)$ and 1:100 $(w / w)$, respectively) were added to the duodenal mix. Aliquots were removed over the 120 min digestion time course and proteolysis was stopped by addition of a two-fold excess of soybean Bowmann-Birk trypsin-chymotrypsin inhibitor above that calculated to inhibit trypsin and chymotrypsinin of the digestion mix. The control was carried out by incubating the sample without 
the proteases for $120 \mathrm{~min}$. The samples were then analyzed using the SDS-PAGE (12\%) procedure described below.

\subsubsection{Sodium Dodecyl Sulphate Polyacrylamide Gel Electrophoresis (SDS-PAGE)}

For SDS-PAGE of FFSs, an aliquot of $5 \mu \mathrm{L}$ of sample buffer $(15 \mathrm{mM}$ of Tris-HCl, $\mathrm{pH} 6.8$, containing $0.5 \%(w / v)$ of SDS, $2.5 \%(v / v)$ of glycerol, $200 \mathrm{mM}$ of $\beta$-mercaptoethanol, and $0.003 \%(w / v)$ of bromophenol blue) were added to aliquots of $20 \mu \mathrm{L}$ of FFS (either untreated or mTGase treated) and analyzed by $12 \%$ SDS-PAGE. The SDS-PAGE of cast films was carried out by dissolving $20 \mathrm{mg}$ of each film in $250 \mu \mathrm{L}$ of sample buffer. The samples were treated at $100{ }^{\circ} \mathrm{C}$ for $5 \mathrm{~min}$, and then centrifuged for $10 \mathrm{~min}$ at $13000 \times \mathrm{g}$. Three $\mu \mathrm{L}$ of each supernatant were analyzed by SDS-PAGE (12\%). For the analysis of film digestion carried out under physiological conditions, $5 \mu \mathrm{L}$ of sample buffer were added to $20 \mu \mathrm{L}$ of each protolyzed film sample and analyzed by $12 \%$ SDS-PAGE.

In all cases SDS-PAGE was performed as described by Laemmli [21], at constant voltage (80 V for 2-3 h), and the proteins were stained with Coomassie Brilliant Blue R250 (Bio-Rad, Segrate, Milan, Italy). Bio-Rad Precision Protein Standards were used as molecular weight markers.

\subsubsection{Densitometry Analysis}

Densitometry analysis was carried out by means of Image Lab software (version 5.2.1) from Bio-Rad Laboratories. Each SDS-PAGE image was analyzed by detecting all the lanes and protein bands. Protein bands, possessing a relative molecular mass $(\mathrm{Mr})$ of $50 \mathrm{kDa}$ were used to determine the band intensity of film digested in the absence of mTGase respect to the control carried out without proteases. Protein bands $>250 \mathrm{kDa}$ were used to determine the band intensity of film digested in the presence of the microbial enzyme with respect to control incubated without proteolytic enzymes.

\subsection{Statistical Analysis}

All data were analyzed by means of JMP software 5.0 (SAS Institute, Cary, NC, USA), used for all statistical analyses. The data were subjected to analysis of variance, and the means were compared using the Tukey-Kramer HSD test. Differences were considered to be significant at $p<0.05$.

\section{Results and Discussion}

\subsection{Stability of Grass Pea Flour Suspension and FFSs}

In order to evaluate the $\mathrm{pH}$ stability of grass pea flour dissolved in water at a concentration of $1 \mathrm{mg} \mathrm{mL}^{-1}$, a titration as function of $\mathrm{pH}$ was carried out to measure Zeta-potential. The charge of particles depends on the solvent used [22]. Zeta-potential is a function of the surface charge of the particle, of adsorbed layer at the interface, and of the nature and composition of the surrounding suspension medium. Generally, Zeta-potential values higher than $\pm 25 \mathrm{mV}$ indicate that the solution is quite stable [22]. The data reported in Figure 1 show a moderate stability of grass pea flour suspension, in fact, the potential changes from +27 to $-25 \mathrm{mV}$ by varying the $\mathrm{pH}$ from 2 to 12 . At $\mathrm{pH} 4$, the suspension became unstable $(0.01 \pm 0.53 \mathrm{mV})$ since this $\mathrm{pH}$ is close to isoelectric point of grass pea proteins (globulins and albumins), which are in the range of 4-6, as also demonstrated by Romano et al. by performing two-dimensional gel electrophoresis [23]. Also, the dimension of particles was quite stable (data not shown) during the titration, being the main particle size diameter equal to roughly $200 \mathrm{~nm}$ of diameter for all the pHs analyzed (data not shown).

FFSs were prepared, both in the presence and the absence of mTGase, at $\mathrm{pH} 9$, since, as reported in Figure 1, we have an acceptable stability at this $\mathrm{pH}$ (Zeta-potential $=-25 \mathrm{mV}$ ). After the preparation, $1 \mathrm{~mL}$ of each solution was analyzed at Zetasizer Nano-ZSP (Malvern ${ }^{\circledR}$, Worcestershire, UK) to confirm the stability.

In Table 1 results about average size, polydispersity index and Zeta-potential of FFSs are reported. The solutions possess a similar Zeta-potential, regardless the presence of mTGase. The average size 
seems to be slightly reduced in the FFS prepared in the presence of the enzyme as already reported by Porta et al. [8]. It is important to note that polydispersity index is around 0.5 indicating that the size of particles is quite uniform in both the systems.

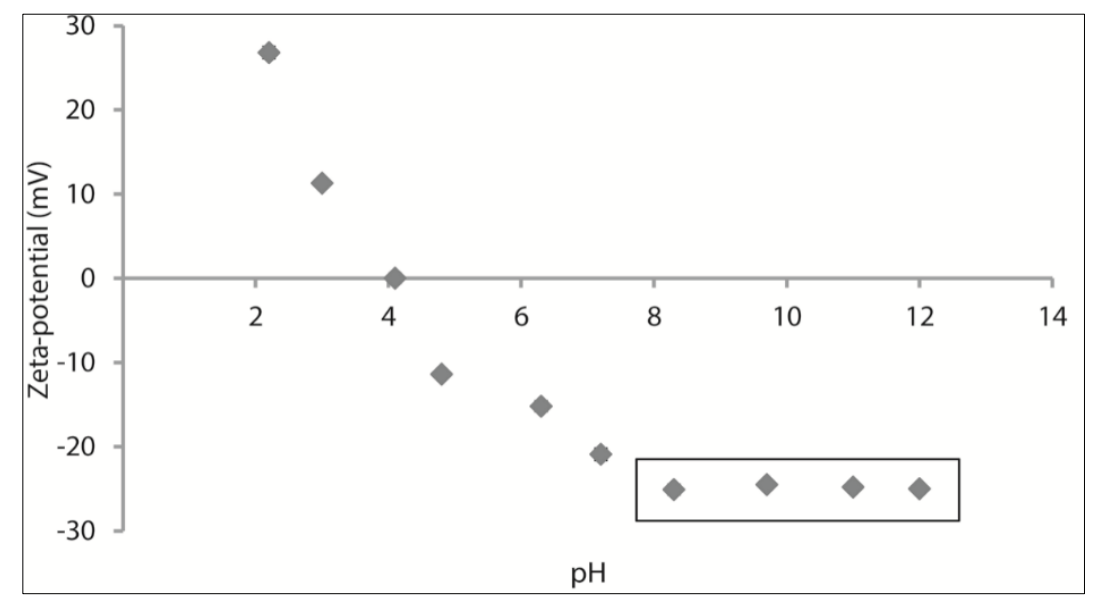

Figure 1. Zeta-potential of grass pea flour suspension as function of $\mathrm{pH}$. Values in the frame represent the Zeta-potential range of stability.

Table 1. Average size, polydispersity index and Zeta-potential of FFSs treated or not by mTGase.

\begin{tabular}{cccc}
\hline Sample pH 9 & Average Size (d/nm) & Polydispersity Index & Zeta-Potential (mV) \\
\hline FFS & $139.40 \pm 1.06^{\mathrm{a}}$ & $0.53 \pm 0.01^{\mathrm{a}}$ & $-27.10 \pm 1.90^{\mathrm{a}}$ \\
FFS + mTGase & $127.30 \pm 2.50^{\mathrm{a}}$ & $0.57 \pm 0.02^{\mathrm{a}}$ & $-28.00 \pm 1.63^{\mathrm{a}}$ \\
\hline
\end{tabular}

Values are mean \pm standard deviation; Means followed by the same letters are not significant different (Tukey-Kramer test, $p<0.05$ ).

\subsection{Modification of Grass Pea Flour Proteins by Means of mTGase}

Both FFSs and cast films were analyzed by means of SDS-PAGE (12\%). The Figure 2 demonstrated that mTGase was able, under these experimental conditions, to modify grass pea proteins. In fact, from the gel (Figure 2) it is possible to note the formation of $\mathrm{Mr}$ polymers and the concomitant disappearance of lower $\mathrm{Mr}$ protein bands in the sample treated with mTGase both in FFSs (Figure 2A) and the solubilized films (Figure 2B), indicating that the mTGase-catalyzed reaction occurs also in the casting system. This result was also supported by viscosity analysis that demonstrated that FFS treated with mTGase has a higher viscosity than the one untreated (Supplementary Materials). An increase of viscosity is due to mTGase activity that, by forming intra and intermolecular $\varepsilon-\mathrm{N}-(\gamma$-glutamyl)-lysine crosslinks between proteins, reinforces the network. These results are in good agreement with those obtained by Nio et al. [24], and Temiz et al. [25] that studied the gelation of casein and soybean globulins by mTGase, demonstrating that the enzyme treatment increases the viscosity of solution. 


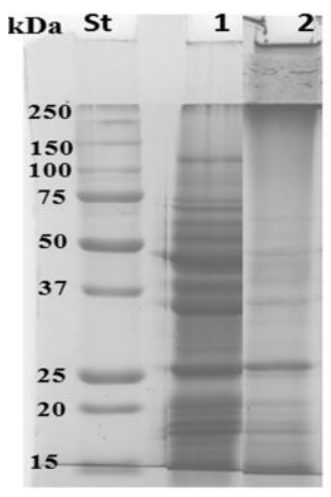

(A)

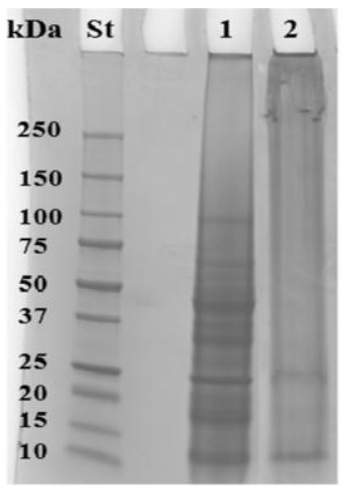

(B)

Figure 2. Panel A-SDS-PAGE of untreated (lane 1) and mTGase-treated (lane 2) FFSs. Panel B-SDS-PAGE of solubilized films cast in the absence (lane 1) and presence (lane 2) of mTGase. St, Molecular weight standards, Bio-Rad. (A) FFSs; (B) FILMS.

\subsection{Opacity}

As shown in Table 2, grass pea-based films, cast in the absence of mTGase, possess an opacity value of $7.74 \pm 0.26 \mathrm{~A}_{600 \mathrm{~nm}} / \mathrm{mm}$ that is similar to the ones obtained by Shevkani et al. [16] which studied hydrocolloid edible films made up of proteins from bean (Phaseulus vulgaris) and pea (Pisum sativum). mTGase-treated films have a opacity value $\left(4.04 \pm 0.06 \mathrm{~A}_{600 \mathrm{~nm}} / \mathrm{mm}\right)$ that is statistically lower $(p<0.05)$ than the ones exhibited by grass pea-based films. The opacity was also determined in traditional commercial plastics such as cellulose triacetate (CTA) and polypropylen (PP5). As expected CTA, glossy plastic sheets used for projecting, appeared very transparent $\left(0.53 \pm 0.08 \mathrm{~A}_{600 \mathrm{~nm}} / \mathrm{mm}\right)$, whereas PP5, normally used for bakery products, macroscopically opaque, showed an opacity value equal to $32.02 \pm 3.35 \mathrm{~A}_{600 \mathrm{~nm}} / \mathrm{mm}$.

Table 2. Opacity of grass pea flour film cast with and without mTGase, compared to commercial plastics.

\begin{tabular}{ccc}
\hline Film Features & Thickness $(\mathbf{m m})$ & Opacity $^{\left(\mathbf{m m}^{\mathbf{- 1}}\right)}$ \\
\hline Grass Pea-Based Films & $0.084 \pm 0.005^{\mathrm{b}}$ & $7.74 \pm 0.26^{\mathrm{b}}$ \\
Grass Pea-Based Films + mTGase & $0.12 \pm 0.02^{\mathrm{a}}$ & $4.04 \pm 0.06^{\mathrm{c}}$ \\
Kidney Bean-Based Films $^{*}$ & $0.064 \pm 0.002$ & $8.9 \pm 0.3$ \\
Field Pea-Based Film * & $0.064 \pm 0.002$ & $7.3 \pm 0.3$ \\
CTA & $0.131 \pm 0.001^{\mathrm{a}}$ & $0.54 \pm 0.09^{\mathrm{d}}$ \\
PP5 & $0.054 \pm 0.003^{\mathrm{c}}$ & $32.02 \pm 3.35^{\mathrm{a}}$ \\
\hline
\end{tabular}

Values are mean \pm standard deviation; Means followed by the same letters are not statistically different (Tukey-Kramer test, $p<0.05$ ); ${ }^{*}$ Data from Shevkani et al. [16]; CTA, cellulose triacetate; PP5, polypropylene.

\subsection{Scanning Electron Microscopy (SEM)}

The film both cast in the presence and absence of mTGase macroscopically appear quite handleable and flexible with a homogeneous structure. Figure 3 shows the SEM images of untreated and mTGase-treated bioplastics. As it is possible to see from Figure 3A, the surface of film cast in the absence of $\mathrm{mTG}$ Tase has a very heterogeneous structure with a high grade of roughness and deep cracks. On the other hand, film surface of films treated with mTGase appears smoother and homogeneous. This observation can be better appreciated in the cross sections of the films, shown in Figure 3B, where the untreated film is highly wrinkled, appearing not compact; instead in the presence of mTGase the film sections appear more homogeneous and uniform, with less cracks. These results reflect those obtained by Giosafatto et al. [3] and Mariniello et al. [26] that state that mTGase treatment confers a smoother and compact structure in pectin and phaseolin-based films. 

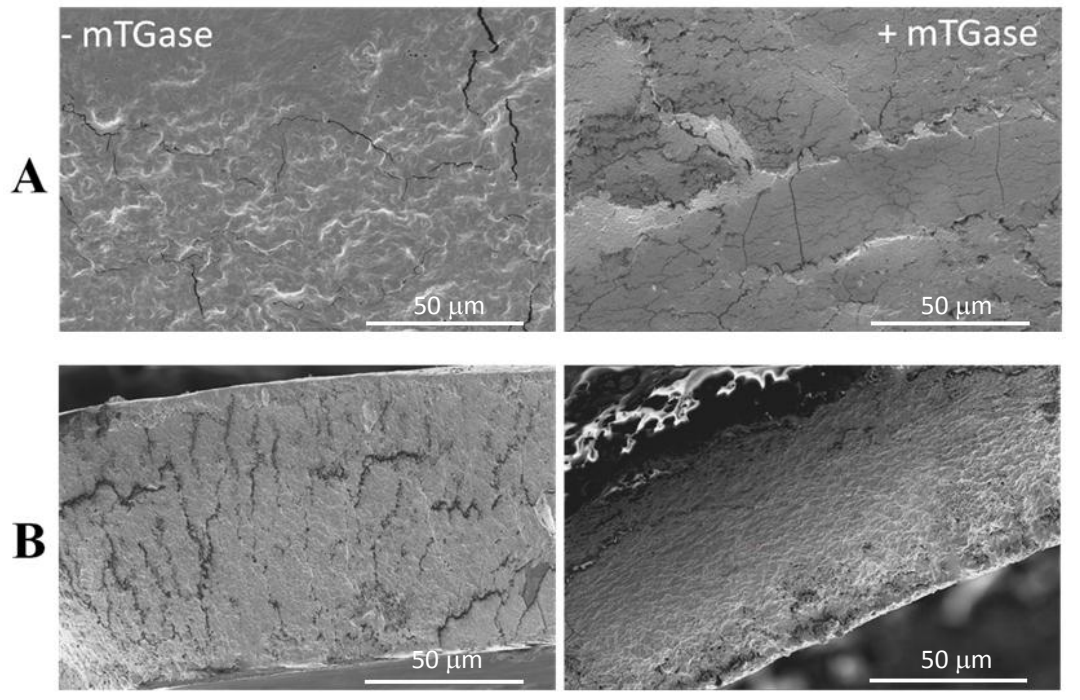

Figure 3. SEM micrographs of surface (A) and cross-sections (B) at $2600 \times$ magnification of grass pea flour-based films prepared in the absence and the presence of mTGase.

\subsection{Oral, Gastric and Duodenal in Vitro Digestion of Grass Pea Flour-Based Edible Films}

Gastric and duodenal digestion experiments were performed under physiological conditions in order to study the possible digestion of the films by the human gut $[3,18]$. As it is possible to note from SDS-PAGE (12\%) shown in Figure 4A unmodified proteins are more susceptible to be digested in the gastric environment than the mTGase-crosslinked ones (Figure 4B). In fact, low $\mathrm{Mr}$ proteins occurred only following the pepsin hydrolysis of untreated grass pea proteins; on the other hand, the mTGase-catalyzed polymers seemed quite resistant and stable even after $60 \mathrm{~min}$ of incubation with pepsin (Figure 4B). In fact, densitometry analysis showed (lower part of Figure 4B) that mTGase-modified forms start being digested only after 20 min incubation with pepsin, and about $76 \%$ of these polymers were still present following $60 \mathrm{~min}$ incubation in comparison to the band intensity of control (lower part of Figure 4B), whereas the undigested proteins represented only the $36 \%$ in the samples that were not subjected to mTGase-mediated modification (lower part of Figure 4A).
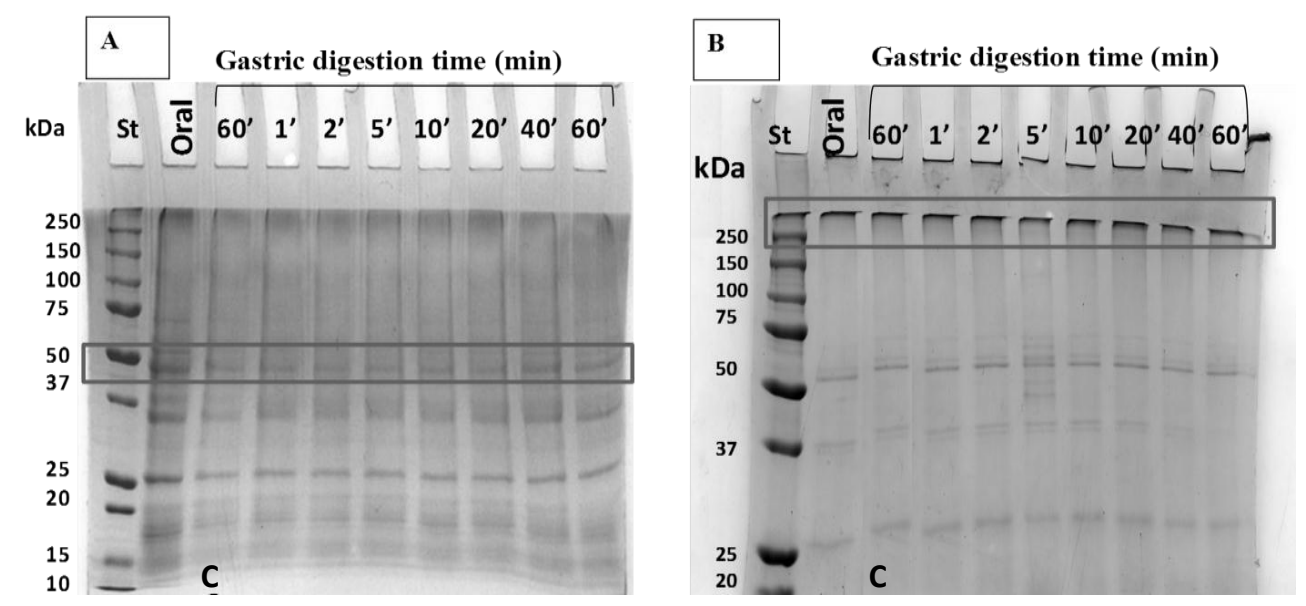

Band intensity (\%) $100 \quad 100 \quad 100 \quad 99 \quad 70 \quad 68 \quad 58 \quad 36$

Band intensity (\%) $\quad 100 \quad 100 \quad 100 \quad 100 \quad 77 \quad 76 \quad 76$

Figure 4. (A) Oral and gastric in vitro digestion and densitometry analysis of $50 \mathrm{kDa}$ protein bands of grass pea film cast without mTGase; (B) Oral and gastric in vitro digestion and densitometry analysis of protein bands of $>250 \mathrm{kDa}$ of grass pea film cast in the presence of mTGase (33 U/g). C is control sample incubated without pepsin. St, Molecular weight standards, Bio-Rad. 
The samples obtained after $60 \mathrm{~min}$ of pepsin digestion were further processed by recurring to trypsin and chymotrypsin, with the aim of mimicking duodenal digestion (Figure 5). We found that both unmodified (Figure 5A) and mTGase-modified (Figure 5B) were more difficult to be digested, even though, once again, the samples incubated in the absence of the crosslinking enzyme appeared more prone to be hydrolyzed by the intestinal enzymes. mTGase-derived polymers are gradually digested and after 120 min incubation (lower part of Figure 5B) with trypsin and chymotrypsin, $61 \%$ of unbroken polymers are still detectable. On the contrary, densitometry analysis of residual intact $50 \mathrm{kDa}$ protein present in the unmodified grass pea flour indicated that $41 \%$ of protein was observed still intact following 120 min digestion with trypsin and chymotrypsin (lower part of Figure 5A). These results clearly indicate that the TGase-mediated intra- and inter-molecular crosslinks confer resistance to gastric and duodenal digestion as demonstrated by other proteins when modified by mTGase [18,27]. These characteristics make such materials usable as scaffolds for the incorporation of active molecules to be delivered in the intestinal tract.
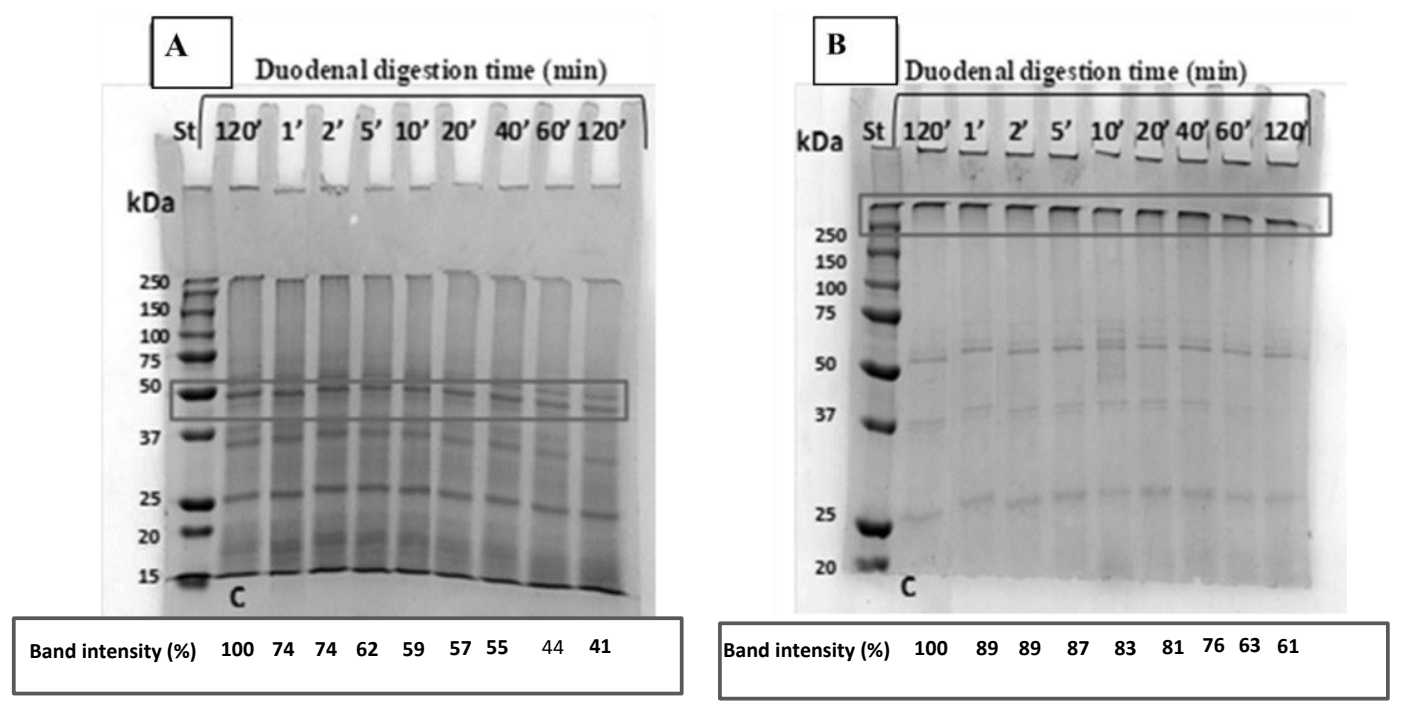

Figure 5. (A) Duodenal in vitro digestion and densitometry analysis of $50 \mathrm{kDa}$ protein bands of grass pea film cast without mTGase; (B) Duodenal in vitro digestion and densitometry analysis of protein bands of $>250 \mathrm{kDa}$ ) of grass pea film cast in the presence of mTGase (33 U/g). SDS-PAGE $12 \%$. Molecular weight standard, Bio-Rad. C is control sample incubated without chymotrypsin and trypsin. St, Molecular weight standards, Bio-Rad.

\subsection{Mechanical Properties}

Tensile strength (TS), Elongation to break (EB) and Young's Modulus (YM) are shown in Table 3. As it possible to see, TS of grass pea flour-based film mTGase-untreated is lower than the one treated with $\mathrm{mTGase}$. These results are in agreement with data reported by our research group [6]. The mTGase induces an increasing of TS because of the occurrence of the mTGase-catalyzed isopeptide bonds within film matrix [28-31]. Also, EB is higher for grass pea flour-based film treated with mTGase than the one performed by untreated sample. It has been reported that deamidated gluten films crosslinked by mTGase showed a gaining of EB likely due to the formation of covalent linkages by mTGase which confers more flexibility [31]. These results are also in agreement with the ones obtained by Mariniello et al. [32], and Tang et al. [33], who suggest that there is a development of a more compact and more elastic film structure after the mTGase treatment. YM data show that the films cast in the absence of mTGase are more rigid than the ones cast with mTGase, the latter possessing lower values of YM. The results reflect those reported from Porta et al. [6], that studied bitter vetch protein concentrate (BVPC) films treated or not with mTGase and affirmed that a treatment with the microbial enzyme induces an increase of resistance and a reduction of stiffness (Table 3). Moreover, from Table 3 it is possible to compare mechanical properties of grass pea flour based-films with those 
performed by Viscofan ${ }^{\circledR}$ and Mater $\mathrm{Bi}^{\circledR}$ [34] plastics, already available on the market and based on natural molecules. In particular, Viscofan ${ }^{\circledR}$ is obtained from collagen, cellulose and fiber-reinforced cellulose [35], whereas Mater $\mathrm{Bi}^{\circledR}$ is made up of corn starch mixed with some vegetal oils [36] in order to improve the technological features. Viscofan ${ }^{\circledR}$ has a higher value of TS and YM (Table 3) than our bioplastics prepared both in the presence and the absence of mTGase, demonstrating that this bioplastic is more mechanically resistant but more rigid than our bioplastics.

On the other hand, EB (Table 3) performed by Viscofan ${ }^{\circledR}$ is lower than that one performed by grass pea flour based-film, indicating that the latter is more extensible than the commercial bioplastic. As far as Mater $\mathrm{Bi}^{\circledR}$ is concerned, it is possible to note again that the grass pea flour-based bioplastics are less resistant, less stiff and less extensible then the starch-based one (Table 3).

Table 3. Mechanical properties of films cast in the presence and the absence of mTGase compared to commercial plastics.

\begin{tabular}{|c|c|c|c|}
\hline Film Type & TS (MPa) Resistance & EB (\%) Extensibility & YM (MPa) Stiffness \\
\hline Films & $0.70 \pm 0.03^{b}$ & $32.2 \pm 4.4^{b}$ & $26.2 \pm 0.7^{a}$ \\
\hline Films + mTGase & $1.04 \pm 0.10^{\mathrm{a}}$ & $59.1 \pm 6.1^{\mathrm{a}}$ & $17.1 \pm 2.8^{b}$ \\
\hline * BVPC & $1.59 \pm 0.18$ & $32.08 \pm 2.52$ & $78.14 \pm 3.04$ \\
\hline${ }^{*}$ BVPC + mTGase & $2.14 \pm 0.47$ & $21.04 \pm 1.29$ & $65.13 \pm 2.10$ \\
\hline${ }^{* *}$ Viscofan NDX ${ }^{\circledR}$ & $36.6 \pm 8.1$ & $13.1 \pm 2.9$ & $356 \pm 29$ \\
\hline ** Mater Bi (S-301) ${ }^{\circledR}$ & $18.4 \pm 2.7$ & $317.9 \pm 35.9$ & $75.2 \pm 2.7$ \\
\hline
\end{tabular}

Values are mean \pm standard deviation; Means followed by the same letters are not significant different (Tukey-Kramer test, $p<0.05$ ); * Data from Porta et al. [6]; ${ }^{* *}$ Data from Porta et al. [34].

\section{Conclusions}

It has been demonstrated that grass pea flour suspension treated or not with mTGase in the presence of a very low amount (8\%) of glycerol, used as plasticizer, is able to produce edible films. Zeta-potential and polydispersity index of the resulting FFSs do not seem to be affected by treatment with mTGase, while average protein agglomerate size appears to be slightly affected by enzyme treatment, resulting on a reduction of particle size. Optical analyses show that grass pea flour-based films are quite transparent in the presence of mTGase, the film opacity being 7 times greater than that performed by the transparent CTA and 8 times lower than the opaque PP5. Morphology studies demonstrated that mTGase confers a smoother and uniform structure as evident from the SEM micrographs of both film surface and cross-section. Digestibility analysis carried out under physiological conditions demonstrated that the grass pea flour proteins were more easily broken down by both gastric and duodenal proteolytic enzymes when the bioplastics were prepared in the absence of mTGase, whereas, the enzyme was able to produce high molecular weight polymers that resulted very resistant to the hydrolysis. Finally, mechanical analyses showed that the bioplastics prepared in the presence of mTGase were more resistant, more extensible and less rigid that the ones prepared in the absence of the enzyme. Further studies will be devoted to assess barrier properties toward $\mathrm{O}_{2}, \mathrm{CO}_{2}$ and water vapor permeability

Supplementary Materials: The following are available online at http:/ /www.mdpi.com/2079-6412/8/12/435/s1, Figure S1: Specific viscosity of grass pea flour FFSs prepared in the absence and the presence of mTGase.

Author Contributions: Conceptualization, C.V.L.G. and L.M.; Methodology, A.D, A.A.-A and V.R.; Software, M.E.; Validation, C.V.L.G. and L.M.; Formal Analysis, L.M.; Resources, C.V.L.G. and L.M.; Data Curation, A.A.-A and M.E..; Writing-Original Draft Preparation, C.V.L.G.; Writing-Review \& Editing, C.V.L.G. and L.M.; Visualization, A.D.; Supervision, L.M.; Project Administration, C.V.L.G.; Funding Acquisition, C.V.L.G. and L.M.

Funding: This work was supported by "MINISTERO DELLE POLITICHE AGRICOLE, ALIMENTARI, FORESTALI E DEL TURISMO (MIPAAFT) (contributi per il finanziamento dei progetti innovativi relativi alla ricerca ed allo sviluppo tecnologico nel campo della "shelf life" dei prodotti alimentari e al confezionamento dei medesimi, finalizzati alla limitazione degli sprechi alimentari nonché per il finanziamento dei progetti di servizio civile, CUP J57G17000190001). 
Acknowledgments: We are grateful to Maria Fenderico for her helpful technical assistance.

Conflicts of Interest: The authors declare that they do not have any conflicts of interests.

\section{References}

1. Geyer, R.; Jambeck, J.R.; Law, K.L. Production, use, and fate of all plastics ever made. Sci. Adv. 2017, 3, 7-11. [CrossRef] [PubMed]

2. Sabbah, M.; Di Pierro, P.; Cammarota, M.; Dell'Olmo, E.; Arciello, A.; Porta, R. Development and properties of new chitosan-based films plasticized with spermidine and/or glycerol. Food Hydrocoll. 2019, 87, 245-252. [CrossRef]

3. Giosafatto, C.V.L.; Di Pierro, P.; Gunning, P.; Mackie, A.; Porta, R.; Mariniello, L. Characterization of citrus pectin edible films containing transglutaminase-modified phaseolin. Carbohydr. Polym. 2014, 106, 200-208. [CrossRef] [PubMed]

4. Giosafatto, C.V.L.; Di Pierro, P.; Gunning, A.P.; Mackie, A.; Porta, R.; Mariniello, L. Trehalose containing hydrocolloid edible films prepared in the presence of transglutaminase. Biopolymers 2014, 101, 931-937. [CrossRef] [PubMed]

5. Materials European Bioplastics V. Available online: https://www.european-bioplastics.org/bioplastics/ materials / (accessed on 1 October 2018).

6. Porta, R.; Di Pierro, P.; Rossi-Marquez, G.; Mariniello, L.; Kadivar, M.; Arabestani, A. Microstructure and properties of bitter vetch (Vicia ervilia) protein films reinforced by microbial transglutaminase. Food Hydrocoll. 2015, 50, 102-107. [CrossRef]

7. Falguera, V.; Quintero, J.P.; Jiménez, A.; Muñoz, J.A.; Ibarz, A. Edible films and coatings: Structures, active functions and trends in their use. Trends Food Sci. Technol. 2011, 22, 292-303. [CrossRef]

8. Porta, R.; Di Pierro, P.; Sabbah, M.; Regalado-Gonzales, C.; Mariniello, L.; Kadivar, M.; Arabestani, A. Blend films of pectin and bitter vetch (Vicia ervilia) proteins: Properties and effect of transglutaminase. Innov. Food Sci. Emerg. Technol. 2016, 36, 245-251. [CrossRef]

9. Rossi Marquez, G.; Di Pierro, P.; Mariniello, L.; Esposito, M.; Giosafatto, C.V.L.; Porta, R. Fresh-cut fruit and vegetable coatings by transglutaminase-crosslinked whey protein/pectin edible films. LWT Food Sci. Technol. 2017, 75, 124-130. [CrossRef]

10. Campbell, C.G. Grass Pea, Lathyrus Sativus L.; Promoting the conservation and use of underutilized and neglected crops; IPGRI: Rome, Italy, 1997; Volume 18, pp. 1-91.

11. Al-Asmar, A.; Naviglio, D.; Giosafatto, C.V.L.; Mariniello, L. Hydrocolloid-based coatings are effective at reducing acrylamide and oil content of french fries. Coatings 2018, 8, 147. [CrossRef]

12. Kieliszek, M.; Misiewicz, A. Microbial transglutaminase and its application in the food industry. A review. Folia Microbiol. 2014, 59, 241-250. [CrossRef] [PubMed]

13. Sorrentino, A.; Giosafatto, C.V.L.; Sirangelo, I.; De Simone, C.; Di Pierro, P.; Porta, R.; Mariniello, L. Higher susceptibility to amyloid fibril formation of the recombinant ovine prion protein modified by transglutaminase. Biochim. Biophys. Acta. 2012, 1822, 1509-1515. [CrossRef] [PubMed]

14. Porta, R.; Giosafatto, C.V.L.; Di Pierro, P.; Sorrentino, A.; Mariniello, L. Transglutaminase-mediated modification of ovomucoid. Effects on its trypsin inhibitory activity and antigenic properties. Amino Acids. 2013, 44, 285-292. [CrossRef] [PubMed]

15. Kjeldahl, J. Neuemethodezurbestimmung des stickstoffs in organischenkörpern. Zeitschrift für Analytische Chemie 1883, 22, 366-382. [CrossRef]

16. Shevkani, K.; Singh, N. Relationship between protein characteristics and film-forming properties of kidney bean, field pea and amaranth protein isolates. Int. J. Food Sci. Technol. 2015, 50, 1033-1043. [CrossRef]

17. ASTM D882-97 Standard Test Method for Tensile Properties of Thin Plastic Sheeting; ASTM: Philadelphia, PA, USA, 1997.

18. Giosafatto, C.V.L.; Rigby, N.M.; Wellner, N.; Ridout, M.; Husband, F.; Mackie, A.R. Microbial transglutaminase-mediated modification of ovalbumin. Food Hydrocoll. 2012, 26, 261-267. [CrossRef]

19. Minekus, M.; Alminger, M.; Alvito, P.; Balance, S.; Bohn, T.; Bourlieu, C.; Carrière, F.; Boutrou, R.; Corredig, M.; Dupont, D.; et al. A standardised static in vitro digestion method suitable for food-An international consensus. Food Funct. 2014, 5, 1113-1124. [CrossRef] [PubMed] 
20. Bourlieu, C.; Ménard, O.; Bouzerzour, K.; Mandalari, G.; Macierzanka, A.; Mackie, A.R.; Dupont, D. Specificity of Infant Digestive Conditions: Some Clues for Developing Relevant In Vitro Models. Crit. Rev. Food Sci. Nutr. 2014, 54, 1427-1457. [CrossRef] [PubMed]

21. Laemmli, U.K. Cleavage of structural proteins during the assembly of the head of Bacteriophage T4. Nature 1970, 227, 680-985. [CrossRef] [PubMed]

22. Bhattacharjee, S. DLS and Zeta potential-What they are and what they are not? J. Controlled Release 2016, 235, 337-351. [CrossRef] [PubMed]

23. Romano, A.; Giosafatto, C.V.L.; Al-Asmar, A.; Masi, P.; Aponte, M.; Mariniello, L. Grass pea (Lathyrus sativus) flour: Microstructure, physico-chemical properties and in vitro digestion. Eur. Food Res. Technol. 2018, 1-8. [CrossRef]

24. Nio, N.; Motoki, M.; Takinami, K. Gelation of Casein and Soybean Globulins by Transglutaminase. Agric. Biol. Chem. 1985, 49, 2283-2286.

25. Temiz, H.; Dağyıldız, K. Effects of Microbial Transglutaminase on Physicochemical, Microbial and Sensorial Properties of Kefir Produced by Using Mixture Cow's and Soymilk. Korean J. Food Sci. Anim. Resour. 2017, 37, 606-616. [CrossRef] [PubMed]

26. Mariniello, L.; Giosafatto, C.V.L.; Di Pierro, P.; Sorrentino, A.; Porta, R. Synthesis and resistance to in vitro proteolysis of transglutaminase cross-linked phaseolin, the major storage protein from Phaseolus vulgaris. J. Agric. Food Chem. 2007, 55, 4717-4721. [CrossRef] [PubMed]

27. Monogioudi, E.; Faccio, G.; Lille, M.; Poutanen, K.; Mattinen, M. Effect of enzymatic crosslinking of $\beta$-casein on proteolysis by pepsin. Food Hydrocoll. 2011, 25, 71-81. [CrossRef]

28. Motoki, M.; Aso, H.; Seguro, K.; Nio, N. $\alpha$ s1-Caseinfilm prepared using transglutaminase. Agric. Biol. Chem. 1987, 51, 993-996.

29. Mahmoud, R.; Savello, P.A. Solubility and hydrolyzability of films produced by transglutaminase catalytic cross-linking of whey protein. J. Dairy Sci. 1993, 76, 29-35. [CrossRef]

30. Yildirim, M.; Hettiarachchy, N.S. Biopolymers Produced by Cross-linking Soybean 11S Globulin with Whey Proteins using Transglutaminase. J. Food Sci. 1997, 62, 270-275. [CrossRef]

31. Larré, C.; Desserme, C.; Barbot, J.; Gueguen, J. Properties of deamidated gluten films enzymatically cross-linked. J. Agric. Food Chem. 2000, 48, 5444-5449. [CrossRef] [PubMed]

32. Mariniello, L.; Di Pierro, P.; Esposito, C.; Sorrentino, A.; Masi, P.; Porta, R. Preparation and mechanical properties of edible pectin-soy flour films obtained in the absence or presence of transglutaminase. J. Biotechnol. 2003, 102, 191-198. [CrossRef]

33. Tang, C.H.; Jiang, Y.; Wen, Q.B.; Yang, X.Q. Effect of transglutaminase treatment on the properties of cast films of soy protein isolates. J. Biotechnol. 2005, 120, 296-307. [CrossRef] [PubMed]

34. Porta, R.; Di Pierro, P.; Roviello, V.; Sabbah, M. Tuning the functional properties of bitter vetch (Vicia ervilia) protein films grafted with spermidine. Int. J. Mol. Sci. 2017, 18, 2658. [CrossRef] [PubMed]

35. Products and markets-Viscofan. Available online: http://www.viscofan.com/products-and-markets (accessed on 1 October 2018).

36. Uso delle risorse-Materbi. Available online: http://materbi.com/uso-delle-risorse/ (accessed on 1 October 2018).

(C) 2018 by the authors. Licensee MDPI, Basel, Switzerland. This article is an open access article distributed under the terms and conditions of the Creative Commons Attribution (CC BY) license (http://creativecommons.org/licenses/by/4.0/). 